\title{
ArcheoSciences
}

Revue d'archéométrie

33 (suppl.) | 2009

Mémoire du sol, espace des hommes

\section{Probing the surface: Adding depth and detail to surface geophysical surveys using down-hole susceptibility measurements}

Rinita A. Dalan

\section{OpenEdition}

Journals

Electronic version

URL: https://journals.openedition.org/archeosciences/1711

DOI: 10.4000/archeosciences. 1711

ISBN: 978-2-7535-1599-4

ISSN: $2104-3728$

Publisher

Presses universitaires de Rennes

\section{Printed version}

Date of publication: 30 October 2009

Number of pages: $283-285$

ISBN: 978-2-7535-0943-6

ISSN: $1960-1360$

Electronic reference

Rinita A. Dalan, "Probing the surface: Adding depth and detail to surface geophysical surveys using down-hole susceptibility measurements", ArcheoSciences [Online], 33 (suppl.) | 2009, Online since 30 October 2011, connection on 01 February 2022. URL: http://journals.openedition.org/archeosciences/ 1711 ; DOI: https://doi.org/10.4000/archeosciences. 1711 


\title{
Probing the surface: Adding depth and detail to surface geophysical surveys using down-hole susceptibility measurements
}

\author{
Rinita A. DAlan*
}

Key words: Down-Hole Studies, Magnetic Susceptibility, North American Archaeology, Landscape Evolution, Anomaly Interpretation.

Down-hole measurements may complement surface geophysical surveys, providing data on anomaly limits (both vertical and horizontal), quantifying contrasts with surrounding soils, and mapping stratigraphic context. They add a third dimension to the two dimensional maps produced by most geophysical investigations and allow deeper features to be mapped with no loss of resolution. Such information allows an enhanced interpretation of anomalies identified through surface geophysical surveys in a less destructive, expensive, and time-consuming manner than excavation. This approach is particularly useful on low contrast earthen features characteristic of much of the North American prehistoric archaeological record.

Magnetic susceptibility is especially effective as this property is responsive to soil forming factors, including human impacts. In combination with laboratory magnetic studies, down-hole susceptibility surveys can be used to investigate the degree of soil development, to identify buried soils, and to understand landscape evolution, site and feature formation, and post-depositional processes (Dalan 2006, 2008)

Investigations at the Biesterfeldt site, a protohistoric (XVIII $^{\text {th }}$ century AD) earth lodge village in North Dakota, and at the Poverty Point site in Louisiana, a constellation of semicircular earthen ridges and earthen and effigy mounds dating to approximately 1650-1200 BC, illustrate how down-hole susceptibility techniques can enhance surface geophysical surveys. Susceptibilities were recorded using the Bartington MS2H sensor and Multisus FieldPro software at depth increments of $2 \mathrm{~cm}$.

Geophysical research at the Biesterfeldt site was conducted as part of a comprehensive significance study (Dalan et al., 2008). The southern half of the site had been repeatedly plowed while the northern half had not. In the unplowed section, resistance and gradiometer surveys mapped anomalies corresponding to earth lodges, central hearths, pits, trails, and metal artifacts. These features could not be reliably distinguished in the plowed field. Therefore we decided to characterize an earth lodge basin in the unplowed section of the site using down-hole susceptibility techniques and then use this known signature as a means of evaluating anomalies and thus potential earth lodge locations in the plowed field. Figure 1 shows the earth lodge that was characterized using a grid of 26 down-hole tests. Figure 2 presents the results of a single transect of down-hole tests in the plowed field where an intact house basin, including a central hearth, was located. The down-hole investigations also revealed the presence of a buried soil beneath the earth lodge. Subsequent tests excavations suggested this paleosol harbors an earlier occupation.

\footnotetext{
* Minnesota State University Moorhead. (dalanri@mnstate.edu)
} 
Figure 1: Down-hole susceptibility data from House 20 at the Biesterfeldt site produced using ArcheoSurveyor 3D. The earth lodge basin and associated hearth and pit features are indicated by high susceptibility values between $10-35 \mathrm{~cm}$ bs. Enhanced susceptibilities at depth (60-90 cm bs) correlate with a buried soil. (Multiply scaled values by 1.4 E-5 for SI susceptibility).

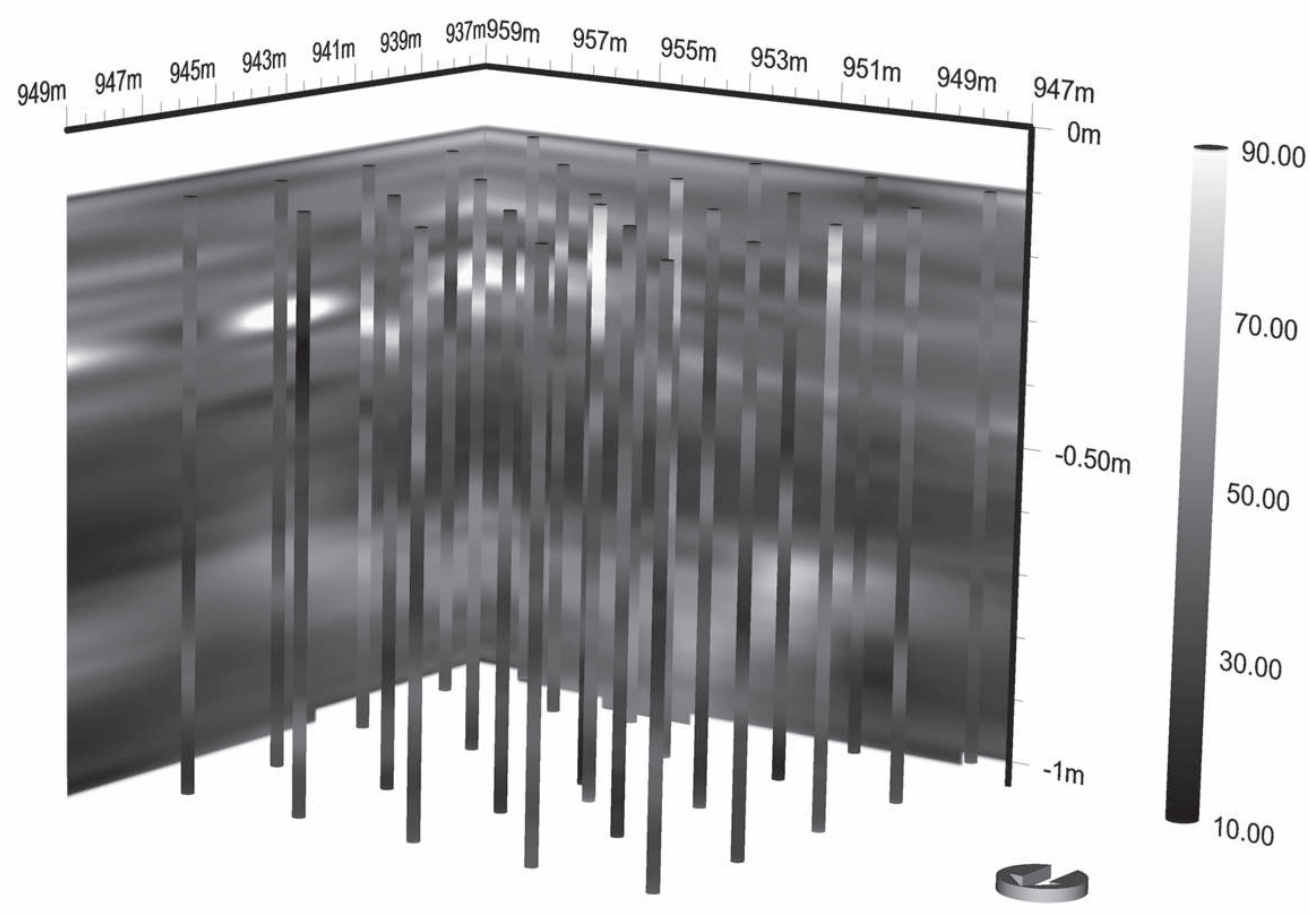

Down-hole investigations at Poverty Point were carried out in conjunction with ongoing geophysical surveys by Drs. Michael Hargrave and R. Berle Clay (Hargrave et al., 2007; Hargrave and Clay, 2006) to aid in understanding the construction and use of the semicircular earthen ridges and a number of large overlapping circular anomalies. Down-hole and laboratory magnetic investigations proved useful for discriminating cultural fills from undisturbed soils, identifying truncated and intact surfaces, and defining constructional episodes. Figure 3 shows the down-hole results for tests located across two of the semi-circular earthen ridges. Data indicate that construction of these two ridges involved excavating soils within the intervening swale. Under the ridges and in the plaza to the east, the pre-construction surface was left intact. On the margins (flanks) of the ridges, shallow zones of highly magnetic soils were confirmed, and the shape and magnetic characteristics of these zones indicated an erosional origin.

Potential difficulties with down-hole research reside in making the approximately 1 -inch diameter hole needed for

Figure 2: Confirmation of an intact house basin at the Biesterfeldt site along a transect of 6 down-hole susceptibility tests spaced at $2.5 \mathrm{~m}$ increments. The three eastern tests, with high susceptibilities between $20-30 \mathrm{~cm}$ bs, revealed an earth lodge basin with a similar signature (i.e., at a similar depth and of a similar magnitude) as House 20 (Figure 1). The tests also provided evidence, in the form of a susceptibility peak at depth, of a buried soil.

\section{House E Down-Hole Transect}

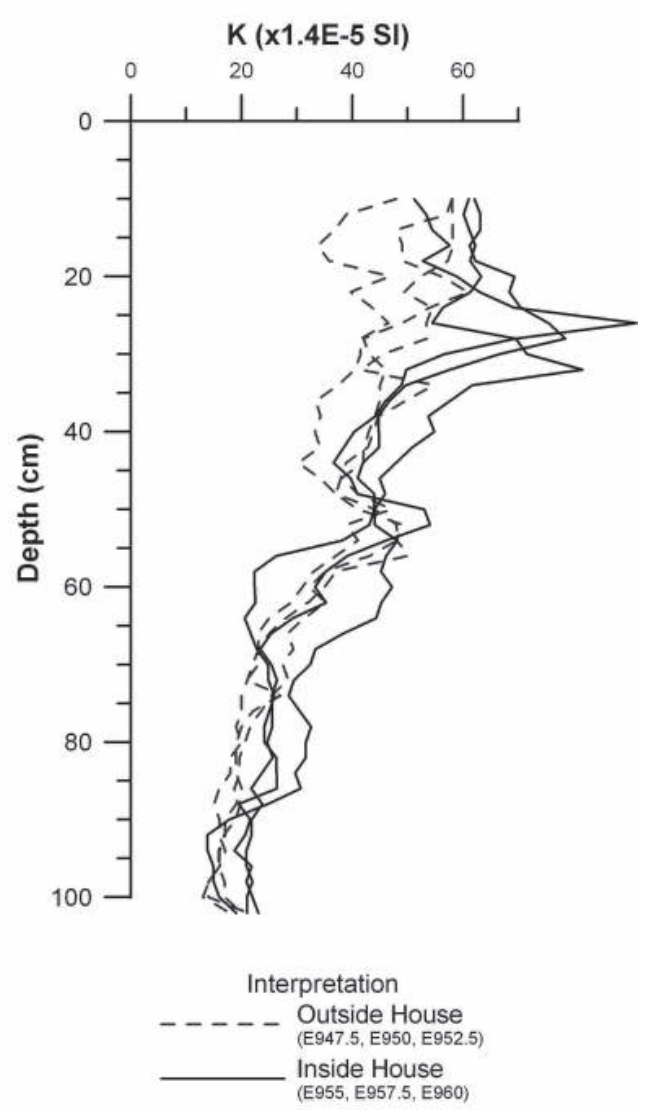


Figure 3: Location of downhole susceptibility tests along the N310 transect at the Poverty Point site (top) together with curtain constructed from recorded values (bottom) produced with ArcheoSurveyor3D (multiply scaled values by E-5 for SI volume susceptibility). Sloping near-surface lenses of high susceptibility soils off the sides of the ridges appear erosional in origin. Relatively high susceptibility values apparent underneath both ridges, indicate the presence of intact buried soils, which were truncated as part of ridge construction in the intervening swale. The buried soil continues into the plaza on the east

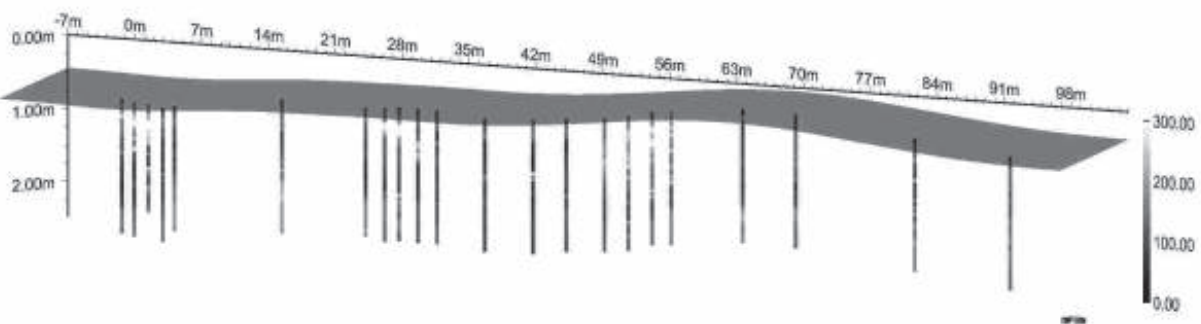
(right).

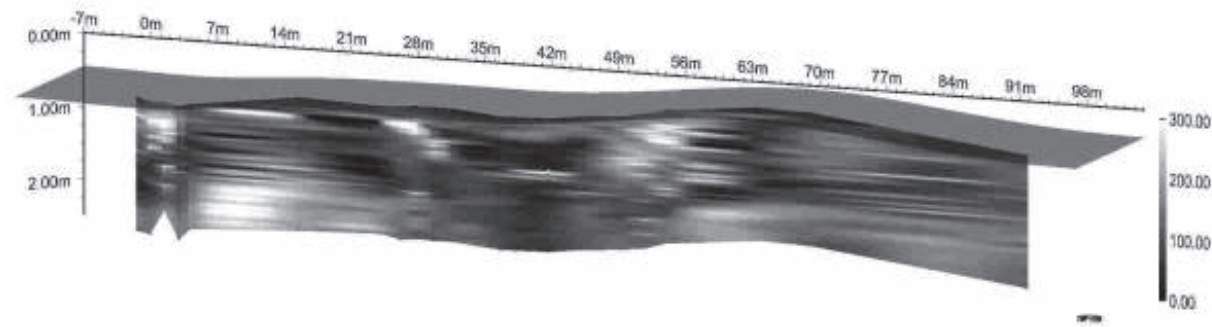

the MS2H sensor. At the Biesterfeldt site, a hand-held pushtube corer was sufficient; at the Poverty Point site, a desire to attain greater depths and harder ground necessitated the use of a Giddings rig mounted on an ATV. Potential gains, however, also derive from having to core before applying the sensor. Soil descriptions and magnetic studies of the subsampled cores were employed at both of these sites to complement the down-hole results. Other down-hole data streams may also be collected once the hole is made.

\section{Acknowledgements}

The Poverty Point investigations were conducted under a permit issued by the Louisiana Division of Archaeology. Funding for the Biesterfeldt research was provided by the Midwest Archeological Center, National Park Service.

\section{References}

Dalan, R. A., 2008. A review of the role of magnetic susceptibility in archaeogeophysical studies in the United States: Recent developments and prospects. Archaeological Prospection, 15:1-31.

Dalan, R. A., 2006. A geophysical approach to buried site detection using down-hole susceptibility and soil magnetic techniques. Archaeological Prospection, 13:182-206.

Dalan, R. A., Holley, G., Michlovic, M., Gooding, E. and WATTERS, H., Jr., 2007. Comprehensive significance study of the Biesterfeldt site (32RM1), Ransom county, North Dakota. Report prepared for the National Park Service, Midwest Archeological Center, Lincoln, NE.

Hargrave, M. L., Britt, T. and Reynolds, M., 2007. Magnetic evidence of ridge construction and use at Poverty Point. American Antiquity, 72(4):757-769.

Hargrave, M. L. and Clay, R. B., 2006. A magnetic field gradient survey at Poverty Point, January 2006. Interim report submitted to the Poverty Point State Historic Site and the Louisiana Division of Archaeology. 